\title{
PENGEMBANGAN PERANGKAT PEMBELAJARAN \\ TEORI EVOLUSI MELALUI MODEL DICK \& CAREY BERBASIS PENDIDIKAN KARAKTER TERHADAP HASIL BELAJAR DAN SIKAP MAHASISWA BIOLOGI DI KOTA MALANG
}

\author{
Riyanto \\ Numala Hindun ${ }^{2}$ \\ Study Program of Biology Education \\ Teacher Training Istitute Budi Utomo of Malang . \\ Email :ryn_kebo@yahoo.com
}

This research is to improve understanding of the concept and attitude on the phenomenon that is occurred, so as to understand the concept of the theory of evolution truelly with the next character-based on education is able to avoid misconception of the concept of evolution, which is still a matter of controversy .

The experimental data is analyzed with analysis of covariance ( Anacova), where the pre-test as a covariate, then further testing is done with a different test Least Significances Different ( LSD ). The statistical analysisis assisted by software of SPSS 14 for Windows, conducted with a significance level of $0.05(\mathrm{p}<0,05)$.

The Results of Anacova test showed that the Instructional Materials Theory of Evolution with Model Dick \& Carey has real significant effect on cognitive achievement with calculation $F$ value of 32.014 with a value of $p=0.000$ is smaller than the alpha value 0.05 which means that the null hypothesisis rejected and the research hypothesisis accepted which states there is influence teaching materials with on Theory of Evolution with Dick \& Carey Model of the students' cognitive achievement and the influence of Instructional Materials of Theory of Evolution by Dick \& Carey Model on the attitude result indicates that calculation F value of 40.873 with a value of $p=0.000$ is smaller than the alpha value of 0.05 which means that the null hypothesisis rejected and the research hypothesisis accepted which states there is the effect of different device Instructional Materials of Theory of Evolution by Dick \& Carey Model for attitude learning outcomes.

Keywords : teaching materials, theory of evolution, dick and carey model

\section{PENDAHULUAN}

Evolusi sampai saat ini merupakan teori yang masih dianggap kontroversial. Evolusi selalu dikaitkan dengan "teori kera" dari Charles Darwin.Pertanyaan yang selalu muncul ketika berbicara tentang evolusi adalah benarkah manusia berasal dari kera?

Secara universal dapat dijelaskan bahwa kendala-kendala yang menjadikan teori evolusi sebagai teori yang kontroversial dikarenakan adanya miskonsepsi dan kondisi pembelajaran yang kurang memperhatikan prakonsepsi yang dimiliki mahasiswa. Kerangka berfikir dan pendekatan ilmu pengetahuan yang digunakan dalam memahami teori evolusi saat ini dinilai kurang tepat. Pada akhirnya konsep yang diterima oleh sebagian orang adalah bahwa teori evolusi secara kasar digambarkan sebagai teori yang mengatakan bahwa manusia berasal dari binatang, jelasnya dari kera. Dengan kata lain konci utama yang sangat berperan membangun pemahaman seseorang terhadap suatu konsep ilmu pengetahuan adalah dosen. 
Berdasarkan hasil observasi dan wawancara di beberapa perguruan tinggi di kota Malang kususnya di IKIP Budi Utomo dan Universitas Muhammadiyah Malang Jurusan pendidikan Biologi terkait dengan teori evolusi masih banyak ditemukan miskonsepsi terkait dengan asal usul kehidupan oleh sebab itulah diperlukan terobosan untuk meminimalisir miskonsepsi dan sikap kontroversi yang banyak terjadi melaluipengembangan bahan ajarteori evolusimodel Dick \& Careyberbasis pendidikan karakter dengan tujuan untuk meminimalisir kesalahan pemahaman konsep dan upaya pembentukan karakter yang baik terkait dengan kontroversi teori evolusi yang selama ini terjadi.

Model pengembangan bahan ajar teori evolusi melalui model Dick \& Carey yang akan dikemas dengan pendidikan karakter yang merupakan salah satu model desain pembelajaran sistematik dan menarik. Dengan kata lain, model Dick \& Carey disusun secara terpogram dengan urut-urutan kegiatan yang sistematis dalam upaya pemecahan masalah belajar. Masalah belajar yang dipecahkan berkaitan dengan sumber belajar oleh karena itu dirancang sesuai dengan kebutuhan dan karakteristik mahasiswa.

Mahasiswa diharapkan tidak hanya pandai secara kognitif, akan tetapi juga memiliki kemampuan dalam dunia nyata, akhlak mulia, penerapan tingkah laku, sebagai realisasi materi yang dipelajari di

Rancangan Eksperimen Faktorial 2 x 2

\begin{tabular}{|l|l|l|l|l|}
\hline Kelompok & $\begin{array}{l}\text { Kemampuan } \\
\text { Akademik }\end{array}$ & Pre-test & Perlakuan & Post-test \\
\hline \multirow{2}{*}{$\begin{array}{l}\text { Eksperimen } \\
\text { A }\end{array}$} & Akademik Atas (X1a) & Y1 & A & Y2 \\
\cline { 2 - 5 } & $\begin{array}{l}\text { Akademik Bawah } \\
(\text { X1b) }\end{array}$ & Y3 & A & Y4 \\
\hline $\begin{array}{l}\text { Kontrol } \\
\text { B }\end{array}$ & Akademik Atas (X2a) & Y5 & B & Y6 \\
\cline { 2 - 5 } & Akademik.Bawah X2b & Y7 & B & Y7 \\
\hline
\end{tabular}

Sumber: dimodifikasi dari Furchan (1982)

Keterangan :

A: Kelompok eksperimen (Pembelajaran Evolusi dengan Model Dick \& Carey) kelas sehingga dosen hendaknya mampu mengubah sistem pembelajaran yang berorientasi pada dosen menjadi pembelajaran yang berorientasi pada mahasiswa (BNSP, 2006).

Berdasarkan latar belakang diatas, serta keinginan yang kuat bagi peneliti untuk menanamkan karakter dan konsep yang benar sebagai upaya meminimalkan kontroversi mengenai Teori Evolusi, maka peneliti sangat tertarik untuk melakukan penelitian tentang "Pengembangan Perangkat Pembelajaran Teori Evolusi melalui model Dick \& Carey Berbasis pendidikan karakter TerhadapHasil Belajar dan Sikap Mahaiswa Biologi Di Kota Malang"

\section{BAHAN DAN METODE}

Rancangan penelitian ini adalah kuasieksperimen. Penelitian dilakukan untuk memperoleh gambaran secara nyata mengenai perbedaan kemampuan, pemahaman konsep dan sikap antara siswa yang melakukan pembelajaran dengan menggunakan bahan ajar teori evolusi melalui model dick \& Carey dengan siswa yang melakukan pembelajaran konvensional pada kemampuan akademik yang berbeda. Desain yang digunakan dalam penelitian ini adalah Pretest-Postest Nonequivalent Control Group Design dengan faktorial 2 x 2 (Campbell \& Stanley, 1963; Ary, 2002; Nasir, 2005). Rancangan eksperimen disajikan dalam Tabel berikut 
$\mathrm{X} 2 \mathrm{a}:$ Kemampuan akademik atas

X2b: Kemampuan akademik bawah

Y1, Y3, Y5, Y7 : pre-test

Y2, Y4, Y6, Y8 : post-test

\section{B. Populasi dan Sampel \\ 1. Populasi}

Populasi penelitian ini adalah Mahasiswa Jurusan Biologi Sekota Malang.

\section{Sampel}

Penentuan sampel dilakukan dengan stratified sampling untuk menentukan kampus yang digunakan sebagai tempat penelitian, sehingga dari penentuan ini diperoleh 2 kelas angkatang 2011, Mahasiswa pada kelas eksperimen dan kelas kontrol diambil $33,3 \% \quad$ (10 Mahasiswa) untuk siswa berkemampuan atas dan 33,3\% (10 Mahasiswa) untuk siswa berkemampuan bawah, sehingga diperoleh jumlah total sampel sebanyak 40 siswa. Pengelompokan kemampuan akademik mahasaswa didasarkan pada IP Semester 5 atau IP Semester 6. Penelitian ini dilaksanakan di Jurusan Biologi Sekota Malang Semester genap Tahun Pelajaran 2012/2013.

\section{Instrumen Penelitian}

Instrumen yang digunakan untuk mengukur variabel terikat dalam penelitian ini adalah: 1) tes, digunakan untuk memperoleh data hasil belajar kognitif, pemahaman konsep dan sikap, 2) lembar observasi, digunakan untuk mengamati keterlaksanaan SAP pada proses pembelajaran. Respons dosen dan mahasiswa juga dimanfaatkan untuk memperkuat informasi tentang implementasi strategi pembelajaran, oleh karena itu disusun angket tanggapan untuk dosen dan mahasiswa.

\section{Tes Kemampuan Kognitif}

Tes digunakan untuk mengukur hasil belajar kognitif dan kemampuan berpikir kritis. Instrumen tes berupa pertanyaan terbuka dan dibuat sesuai dengan kisi-kisi tes. Besarnya skor setiap item ditentukan dengan rubrik yang mengacu pada Hart (1994) dengan skala 0-4. Hasil belajar kognitif yang diukur melalui tes ini adalah dimensi proses kognitif Bloom Taxonomy (1956)yang direvisi oleh Anderson dan Krathwohl (2000), meliputi kemampuan mengingat(C1), memahami(C2), menerapkan(C3), menganalisis(C4), mengevaluasi(C5), dan mencipta(C6).

Instrumen tes disusun oleh peneliti dan pengembangannya mengikuti Aryana (2004) meliputi: 1) penentuan standar kompetensi, 2) analisis kompetensi dasar, 3) penyusunan kisi-kisi, 4) penyusunan tes, 5) penyusunan rubrik, 6) uji ahli, 7) uji lapangan untuk penentuan validitas butir, reliabilitas, daya beda, dan tingkat kesukaran tes.

Instrumen tes disusun oleh peneliti dan pengembangannya mengikuti Arnyana (2004) meliputi: 1) penentuan standar kompetensi, 2) analisis kompetensi dasar, 3) penyusunan kisi-kisi, 4) penyusunan tes, 5) penyusunan rubrik, 6) uji ahli, 7) uji lapangan untuk penentuan validitas butir, reliabilitas, daya beda, dan tingkat kesukaran tesdilakukan sebelum penelitian eksperimen kelas. Uji coba dilakukan terhadap mahasiswa S1 Jurusan Biologi Sekota Malang angkatan sebelumnya yaitu angkatan 2008.

\section{a. Validitas Tes}

Validitas butir tes dihitung dengan koefisien korelasi skor setiap butir dengan skor total. Penghitungan koefisien korelasi dihitung dengan Excel for Windows dan SPSS14 for Windows, dengan kriteria validitas butir dibandingkan antara r-hitung dengan r-tabel, bila r-hitung lebih besar dari r-tabel (r-hitung > r-tabel) maka butir tes dikatakan valid (Arikunto, 2001; Sudijono, 2006; Azwar, 2007). Validitas isi dilakukan oleh ahli.

\section{b. Reliabilitas Tes}

Pengujian reliabilitas instrumen tes menggunakan koefisian reliabilitas dengan rumus Alpha Cronbach (Subana dan 
Sudrajat, 2000; Sugiyono, 2003; Sudijono, 2006; Azwar, 2007). Penghitungan dilakukan dengan memanfaatkan software program SPSS 14 for Windows (Ariyanto, 2006). Rumus Alpha Cronbach menurut Sugiyono (2003) sebagai berikut:

$$
R 1=\frac{K}{K-1}\left\{1-\frac{\sum S t^{2}}{S t^{2}}\right\}
$$

Keterangan:

R1 = reliabilitas instrumen

$\mathrm{K}=$ rata-rata kuadrat antar subjek

$\sum S t^{2}=$ rata-rata kuadrat kesalahan

$S t^{2}=$ varians total

Kriteria uji menurut Arikunto (2001):

$0,80-1,00=$ sangat tinggi

$0,60-0,79=$ tinggi

$0,40-0,59=$ cukup

$0,20-0,399=$ rendah

$0,00-0,199=$ sangat rendah

\section{c. Daya Beda}

Uji daya beda dilakukan terhadap tes aspek kognitif. Menurut Surapranata (2004) dan Sudijono (2006), daya beda ditentukan dengan mengambil $27 \%$ siswa kelompok atas dan $27 \%$ siswa kelompok bawah. Selanjutnya menurut Arikunto (2001), rumus dan kriteria untuk menentukan daya beda adalah:

$$
\mathrm{D}=\frac{B A}{J A}-\frac{B B}{J B}
$$

Keterangan:

$\mathrm{D}$ = daya beda

$\mathrm{BA}=$ kelompok atas yang menjawab benar

$\mathrm{BB}=$ kelompok bawah yang menjawab benar

$\mathrm{JA}=$ jumlah siswa kelompok atas

$\mathrm{JB}=$ jumlah siswa kelompok bawah

Kriteria uji menurut Arikunto (2001):
0,70-1.00 = soal baik sekali

$0,40-0,699=$ soal baik

$0,20-0399=$ soal cukup

$0,00-0,199=$ soal buruk (harus direvisi)

Penghitungan daya beda dilakukan dengan memanfaatkan software program Excel for Windows dan Anates versi 4.

\section{d. Tingkat Kesukaran Tes}

Uji tingkat/taraf kesukaran hanya dilakukan terhadap tes aspek kognitif. Tingkat kesukaran setiap butir dihitung dengan menggunakan rumus yang diadaptasi dari Surapranata (2004) sebagai berikut:

Keterangan:

$$
\mathrm{P}=\mathrm{X} / \mathrm{N}
$$

$\mathrm{P}$ = tingkat kesukaran setiap butir

$\mathrm{X}=$ banyaknya peserta tes dengan jawaban benar

$\mathrm{N}=$ jumlah peserta tes

Kriteria uji menurut Arikunto (2001):

$0,71-1,00=$ soal mudah

$0,31-0,70=$ soal sedang

$0,00-0,30=$ soal sukar

Penghitungan tingkat kesukaran tes dilakukan dengan memanfaatkan software program Excel for Windows dan SPSS 14 for Windows (Ariyanto, 2006).

\section{Tes Sikap}

Sikap mahasiswa mengenai teori evolusi dan penerapannya diukur menggunakan instrumen tes berupa angket/kuesioner menggunakan skala likert dengan lima kategori, yaitu sangat setuju, setuju, ragu-ragu, tidak setuju dan sangat tidak setuju. Instrumen divalidasi menggunakan logical validation, yaitu berupa masukan ahli pendidikan dan Biologi.

\section{Lembar Observasi Keterlaksanaan Rencana Pelaksanaan Pembelajaran}

Lembar observasi keterlaksanaan SAP berisi pelaksanaan skenario pembelajaran dari awal sampai akhir proses pembelajaran dan dilengkapi kolom 
penyataan "terlaksana atau tidak terlaksana". Lembar observasi ini digunakan untuk mengecek seluruh proses pembelajaran yang telah tertuang dalam SAP. Lembar observasi ini disusun oleh peneliti, divalidasi ahli dan diuji keterbacaan oleh Dosen.

\section{Angket Tanggapan Dosen dan Mahasiswa}

Angket digunakan untuk mengumpulkan data tanggapan dosen dan siswa terhadap proses pembelajaran yang dilaksanakan. Tanggapan dosen dan siswa ini digunakan untuk mendukung rekomendasi kemanfaatan strategi pembelajaran, apabila disebarluaskan pada sekolah-sekolah lain. Angket terdiri dari beberapa item dengan alternatif tanggapan yang disertai penjelasan singkat. Angket disusun oleh peneliti dan divalidasi oleh ahli serta diuji keterbacaan oleh dosen dan mahasiswa.

\section{Pengumpulan Data}

Tahap-tahap pengumpulan data dalam penelitian adalah sebagai berikut:

1. Melakukan pretes, digunakan untuk mengetahui hasil belajar kognitif dan sikap. Pretes ini dilakukan sebelum pelaksanaan penelitian eksperimen. Tes dilakukan oleh guru dan peneliti dengan durasi pengerjaan soal 90 menit.

2. Melakukan postes, sebagaimana halnya pretes, postes digunakan untuk mengetahui hasil belajar kognitif dan sikap. Tes ini dilakukan setelah mahasiswa mengikuti seluruh rangkaian pembelajaran penelitian eksperimen. Jawaban mahasiswa diberi skor

\section{HASIL DAN PEMBAHASAN}

Nilai rata-rata hasil belajar kognitif pre test dan post tes untuk kelompok indikator dapat dilihat pada Tabel 1.1 berikut: menggunakan rubrik yang telah dipersiapkan.Observasi keterlaksanaan SAP. Observasi dilakukan oleh dosen dan peneliti dengan memberikan chek list pada pilihan jawaban atas pelaksanaan SAP yang dilampirkan pada SAP dengan pilihan jawaban terlaksana atau tidak terlaksana.

3. Memberikan angket kepada dosen dan mahasiswa untuk memperoleh data tanggapan dosen dan mahasiswa terhadap proses pembelajaran yang telah dilaksanakan.

\section{E. Analisis Data}

Data hasil penelitian eksperimen tersebut dianalisis dengan analisis kovariansi (Anakova), dimana hasil pretest sebagai kovariat, kemudian uji lanjut dilakukan dengan uji beda Least Significances Different (LSD) (Winner, 1971; Sujana 1994; Sastrosupadi, 1995; Winarsunu, 2007). Analisis statistik dibantu dengan softwareSPSS 14 for Windows, dilakukan dengan taraf signifikansi 0,05 $(\mathrm{p}<0,05)$.

Sebelum dilakukan uji hipotesis, terlebih dahulu dilakukan uji prasyarat normalitas dan homogenitas data. Uji normalitas menggunakan uji One-Sample Kolmogorov-Smirnov, sedangkan uji homogenitas menggunakan Leven's Test of Equality of Error Variances (Sujana, 1994). Penghitungan uji dilakukan dengan program SPSS 14 for Windows. Analisis deskriptif rata-rata skor digunakan untuk mendeskripsikan profil hasil belajar kognitif biologi dan kemampuan berpikir kritis. 
Tabel 1.1 Rata-rata Nilai Pre test dan Post test Hasil Belajar Kognitif.

\begin{tabular}{|c|c|c|c|c|c|c|c|c|}
\hline \multirow{2}{*}{ No. } & \multicolumn{2}{|c|}{$\begin{array}{c}\text { Bahan Ajar } \\
\text { Dick \& Carey }\end{array}$} & \multicolumn{2}{c|}{$\begin{array}{c}\text { Bahan Ajar } \\
\text { Dick \& Carey }\end{array}$} & \multicolumn{2}{c|}{ Konvensional } & Konvensional \\
\hline Sampel & \multicolumn{2}{|c|}{$\begin{array}{c}\text { Akademik } \\
\text { Atast }\end{array}$} & \multicolumn{2}{c|}{$\begin{array}{c}\text { Akademik } \\
\text { Bawah }\end{array}$} & \multicolumn{2}{c|}{$\begin{array}{c}\text { Akademik } \\
\text { Atas }\end{array}$} & \multicolumn{2}{c|}{$\begin{array}{c}\text { Akademik } \\
\text { Bawah }\end{array}$} \\
\hline & Pre & Post & Pre & Post & Pre & Post & Pre & Post \\
\hline 1 & 50 & 80 & 31 & 70 & 53 & 79 & 24 & 59 \\
\hline 2 & 62 & 87 & 34 & 71 & 24 & 57 & 25 & 50 \\
\hline 3 & 47 & 83 & 30 & 67 & 47 & 72 & 19 & 43 \\
\hline 4 & 53 & 76 & 26 & 50 & 50 & 69 & 35 & 46 \\
\hline 5 & 40 & 77 & 25 & 57 & 40 & 59 & 39 & 58 \\
\hline 6 & 44 & 83 & 27 & 39 & 59 & 77 & 26 & 46 \\
\hline 7 & 60 & 71 & 30 & 60 & 48 & 79 & 28 & 43 \\
\hline 8 & 50 & 89 & 31 & 49 & 43 & 66 & 15 & 41 \\
\hline 9 & 49 & 73 & 21 & 71 & 45 & 72 & 20 & 50 \\
\hline 10 & 53 & 71 & 19 & 27 & 60 & 59 & 32 & 60 \\
\hline 11 & 57 & 74 & 27 & 57 & 39 & 72 & 31 & 39 \\
\hline 12 & 46 & 71 & 18 & 70 & 58 & 79 & 19 & 52 \\
\hline 13 & 60 & 73 & 29 & 53 & 59 & 85 & 39 & 60 \\
\hline Jumlah & 671 & 1006 & 348 & 741 & 625 & 925 & 352 & 647 \\
\hline Rata-rata & 51,6 & 77,5 & 26,7 & 57 & 48,1 & 71,7 & 27,3 & 49 \\
\hline SD & 5,31 & 6,84 & 5,11 & 6,32 & 5,14 & 6,11 & 5,02 & 6,12 \\
\hline
\end{tabular}

Pada Tabel 1.1 dapat dijelaskan bahwa peserta didik yang belajar dengan bahan ajarteori evolusimodel Dick \& Carey nilai rerata pre test hasil belajar kognitif peserta didik berkemampuan akademik atas dan berkemampuan akademik bawah adalah 51.6 dan 26.7 sedangkan nilai rerata post test adalah 77.5 dan 57. Pada peserta didik yang belajar menggunakan pembelajaran konvensional nilai rerata pre test hasil belajar kognitif peserta didik berkemampuan akademik atas dan berkemampuan akademik bawah adalah 48.1 dan 27.3 sedangkan nilai rerata post test adalah 71.7 dan 49.

Hasil uji statistik pengaruh strategi pembelajaran diperoleh p-level lebih kecil dari alpha 0,05 $(\mathrm{p}<0,05)$ dengan Sig. 0,000. Hal ini berarti Ho tidak diterima, jadi hipotesis penelitian yang menyatakan "Ada ada pengaruh Perangkat Pembelajaran Teori Evolusi Melalui model Dick \& Carey terhadap hasil belajar kognitif" diterima. Rata-rata nilai hasil belajar kognitif peserta didik pada Perangkat Pembelajaran Teori Evolusi Melalui model Dick \& Carey lebih tinggi dibandingkan dengan rata-rata nilai hasil belajar kognitif peserta didik pada model pembelajaran konvensional.

Ringkasan hasil uji anakova pengaruh perlakuan terhadap hasil belajar kognitif dapat dilihat pada Tabel 1.2. 
Tabel 1.2 Ringkasan Hasil Uji Anakova Pengaruh Perlakuan terhadap Hasil Belajar kognitif

\begin{tabular}{|l|r|r|r|r|r|}
\hline Source & $\begin{array}{c}\text { Type III Sum } \\
\text { of Squares }\end{array}$ & \multicolumn{1}{c|}{ df } & \multicolumn{1}{c|}{$\begin{array}{c}\text { Mean } \\
\text { Square }\end{array}$} & \multicolumn{1}{c|}{ F } & \multicolumn{1}{c|}{ Sig. } \\
\hline Corrected Model & $7326.539^{\mathrm{a}}$ & 4 & 2359.099 & 130.04 & .000 \\
\hline Intercept & 1345.130 & 1 & 1444.030 & 93.348 & .000 \\
\hline Pretes & 1283.691 & 1 & 1184.105 & 76.589 & .000 \\
\hline Akademik & 136.676 & 1 & 136.676 & 8.251 & .006 \\
\hline Perlakuan & 467.361 & 1 & 467.361 & 32.014 & .000 \\
\hline Akademik * Perlakuan & 16.172 & 1 & 16.172 & .991 & .327 \\
\hline Error & 729.071 & 49 & 17.491 & & \\
\hline Total & 22671.000 & 48 & & & \\
\hline Corrected Total & 9342.673 & 53 & & & \\
\hline
\end{tabular}

Hasil uji lanjut pengaruh perlakuan terhadap hasil belajar kognitif tertera pada Tabel 1.3 berikut.

Tabel 1.3 Ringkasan Uji lanjut Pengaruh Perlakuan terhadap Hasil Belajar kognitif

\begin{tabular}{|c|c|c|c|c|c|}
\hline Perlakuan & Pretes & Postes & Selisih & Corr & $\begin{array}{c}\text { Notation } \\
\text { LSD }_{0.05}\end{array}$ \\
\hline Kontrol & 39.7000 & 59.2097 & 20.9087 & 55.191 & $\mathrm{~A}$ \\
\hline Eksperimen & 42.0308 & 68.1194 & 24.9876 & 64.612 & $\mathrm{~B}$ \\
\hline
\end{tabular}

Hasil belajar sikap peserta didik dituangkan melalui pengisian angket sikap terhadap konsep asul kehidupan. Pengisian angket sikap peserta didik dilakukan pada bagian akhir dari seluruh proses pembelajaran. Angket sikap terhadap pembelajaran disampaikan kepada seluruh peserta didik yang telah mendapatkan pembelajaran dengan perangkat pembelajaran evulusi dengan Bahan Ajar Dick \& Carey maupun konvensional.
Secara khusus perlu diketahui tingkat pencapaian indikator hasil belajar Sikap yang meliputi kognisi (pernyataan tentang asal usul kehidupan), afeksi (perasaan senang mempelajari evolusi) dan konasi (kecenderungan berperilaku terkait materi dan peran evolusi). Nilai rata-rata hasil belajar Sikappre test dan post tes untuk kelompok eksperimen dan kelompok kontrol tiap indikator dapat dilihat pada Tabel 1.4 berikut.

Tabel 1.4 Rata-rata Nilai Pre test dan Post test Hasil Belajar Sikap.

\begin{tabular}{|c|r|r|r|r|r|r|r|r|}
\hline No. & \multicolumn{2}{|c|}{$\begin{array}{c}\text { Bahan Ajar } \\
\text { Dick \& Carey }\end{array}$} & \multicolumn{2}{c|}{$\begin{array}{c}\text { Bahan Ajar Dick } \\
\text { \& Carey }\end{array}$} & \multicolumn{2}{|c|}{ Konvensional } & \multicolumn{2}{|c|}{ Konvensional } \\
\hline Sampel & \multicolumn{2}{c|}{$\begin{array}{c}\text { Akademik } \\
\text { Atas }\end{array}$} & \multicolumn{2}{c|}{$\begin{array}{c}\text { Akademik } \\
\text { Bawah }\end{array}$} & \multicolumn{2}{|c|}{ Akademik Atas } & \multicolumn{2}{|c|}{$\begin{array}{c}\text { Akademik } \\
\text { Bawah }\end{array}$} \\
\hline & Pre & Post & Pre & Post & Pre & Post & Pre & Post \\
\hline 1 & 39 & 80 & 32 & 73 & 42 & 85 & 31 & 77 \\
\hline 2 & 56 & 84 & 38 & 64 & 43 & 83 & 32 & 58 \\
\hline 3 & 59 & 80 & 19 & 77 & 32 & 72 & 21 & 60 \\
\hline 4 & 50 & 73 & 29 & 69 & 50 & 70 & 30 & 63 \\
\hline 5 & 45 & 84 & 40 & 60 & 41 & 72 & 29 & 54 \\
\hline 6 & 40 & 79 & 43 & 62 & 49 & 78 & 28 & 68 \\
\hline 7 & 60 & 80 & 20 & 53 & 58 & 89 & 30 & 53 \\
\hline
\end{tabular}




\begin{tabular}{|c|r|r|r|r|r|r|r|r|}
\hline 8 & 51 & 77 & 30 & 70 & 50 & 73 & 32 & 59 \\
\hline 9 & 40 & 79 & 21 & 73 & 35 & 70 & 23 & 53 \\
\hline 10 & 47 & 79 & 39 & 62 & 29 & 75 & 39 & 69 \\
\hline 11 & 59 & 73 & 21 & 68 & 43 & 73 & 29 & 50 \\
\hline 12 & 43 & 75 & 27 & 60 & 60 & 80 & 40 & 69 \\
\hline 13 & 51 & 86 & 25 & 62 & 53 & 77 & 32 & 70 \\
\hline Jumlah & 640 & 1029 & 384 & 853 & 585 & 997 & 396 & 803 \\
\hline Rata-rata & 49,2 & 79,15 & 29,54 & 65,61 & 45 & 76,69 & 30,46 & 61,76 \\
\hline SD & 5,64 & 4,41 & 4,10 & 3,53 & 6,45 & 3,21 & 4,95 & 5,29 \\
\hline
\end{tabular}

Pada Tabel 1.4 dapat dijelaskan bahwa peserta didik yang belajar dengan menggunakan Bahan Ajar Evolusi Model Dick \& Carey nilai rerata pretest hasil belajar Sikap peserta didik berkemampuan akademik atas dan berkemampuan akademik bawah adalah 49.2 dan 29.54 sedangkan nilai rerata post test adalah 79.15 dan 65.61. Pada peserta didik yang belajar menggunakan perangkat pembelajaran evolusi melalui strategi konvensional nilai rerata pretest hasil belajar Sikap peserta didik berkemampuan akademik atas dan berkemampuan akademik bawah adalah 45 dan 30.46 sedangkan nilai rerata post test adalah 76.69 dan 61.76 .

Hasil uji statistik pengaruh strategi pembelajaran diperoleh p-level lebih kecil dari alpha 0,05 $(\mathrm{p}<0,05)$ dengan Sig. 0,000. Hal ini berarti Ho tidak diterima, jadi hipotesis penelitian yang menyatakan "Ada pengaruh perangkat Bahan Ajar Teori Evolusi dengan Model Dick \& Carey terhadap hasil belajar kognitif' diterima.

Rata-rata nilai hasil belajar sikap peserta didik pada Bahan Ajar Teori Evolusi dengan Model Dick \& Carey lebih tinggi dibandingkan dengan rata-rata nilai hasil belajar kognitif peserta didik pada strategi konvensional. Apabila dinyatakan dalam persentase, pembelajaran biologi dengan Bahan Ajar Teori Evolusi dengan Model Dick \& Careymemiliki rata-rata nilai hasil belajar kognitif terkoreksi 4.00, lebih tinggi bila dibandingkan dengan pembelajaran biologi dengan strategi konvensional.

Ringkasan hasil uji anakova pengaruh perlakuan terhadap hasil belajar sikap dapat dilihat pada Tabel 1.5

Tabel 1.5 Ringkasan Hasil Uji Anakova Pengaruh Perlakuan terhadap Hasil Belajar sikap

\begin{tabular}{|l|r|r|r|r|r|}
\hline Source & $\begin{array}{c}\text { Type III Sum } \\
\text { of Squares }\end{array}$ & \multicolumn{1}{c|}{ Df } & \multicolumn{1}{c|}{$\begin{array}{c}\text { Mean } \\
\text { Square }\end{array}$} & F & Sig. \\
\hline Corrected Model & $3509.191^{\mathrm{a}}$ & 4 & 739.817 & 129.51 & .000 \\
\hline Intercept & 1789.805 & 1 & 1789.805 & 300.78 & .000 \\
\hline Pretest & 425.040 & 1 & 425.040 & 69.032 & .000 \\
\hline Akademik & 142.302 & 1 & 142.302 & 7.841 & .007 \\
\hline Perlakuan & 270.321 & 1 & 270.321 & 40.873 & .000 \\
\hline Akademik * Perlakuan & 19.023 & 1 & 19.023 & 2.812 & .099 \\
\hline Error & 200.346 & 49 & 6.386 & & \\
\hline Total & 247203.000 & 53 & & & \\
\hline Corrected Total & 3208.519 & 49 & & & \\
\hline
\end{tabular}

a. R Squared $=.911$ (Adjusted R Squared $=.903)$ 
Hasil uji lanjut pengaruh perlakuan terhadap hasil belajar sikap tertera pada Tabel 1.6 berikut.

Tabel 1.6 Ringkasan Uji lanjut Pengaruh Perlakuan terhadap Hasil Belajar sikap

\begin{tabular}{|c|c|c|c|c|c|}
\hline Perlakuan & Pretes & Postes & Selisih & Corr & $\begin{array}{c}\text { Notation } \\
\text { LSD }_{0.05}\end{array}$ \\
\hline Kontrol & 39.6860 & 69.3543 & 26.8867 & 67.092 & $\mathrm{~A}$ \\
\hline Eksperimen & 42.5769 & 74.5221 & 29.9562 & 83.332 & $\mathrm{~B}$ \\
\hline
\end{tabular}

PEMBAHASAN

1. Pengaruh Bahan Ajar Teori Evolusi dengan Model Dick \& Carey terhadap Hasil Belajar Kognitif

Hasil penelitian ini menunjukkan bahwa proses pembelajaran dengan Bahan Ajar Teori Evolusi dengan Model Dick \& Carey berpengaruh nyata terhadap hasil belajar kognitif peserta didik. Peserta didik yang belajar dengan Bahan Ajar Teori Evolusi dengan Model Dick \& Carey memiliki rata-rata nilai hasil belajar kognitif lebih tinggi yaitu dengan nilai 68.1194 dibanding peserta didik yang belajar dengan strategi konvensionalyang sebesar 59.2097. Peningkatan hasil belajar kognitif juga dapat dilihat dari peningkatan rata-rata nilai hasil belajar kognitif sebelum perlakuan (pre test) dibandingkan rata-rata nilai hasil belajar kognitif setelah perlakuan (post test).

Hasil uji Anakova menunjukkan bahwa Bahan Ajar Teori Evolusi dengan Model Dick \&Carey berpengaruh nyata terhadap hasil belajar kognitif dengan nilai $\mathrm{F}$ hitung sebesar 32.014dengan nilai $\mathrm{p}=$ 0.000 lebih kecil dari nilai alpha 0.05 yang berarti hipotesis nol ditolak dan hipotesis penelitian diterima yang menyatakan ada pengaruh Bahan Ajar Teori Evolusi dengan Model Dick \& Carey terhadap hasil belajar kognitif peserta didik.

Kemampuan pendidik dalam menguasai berbagai strategi pembelajaran yang inovatif dan kemampuan mengembangkan perangkat pembelajaran sangat berperan terhadap peningkatkan hasil belajar kognitif.
Penggunakan berbagai macam strategi pembelajaran dapat mengurangi kejenuhan serta dapat meningkatkan motivasi peserta didik sehingga hasil belajar kognetifpeserta didik juga akan naik. Partisipasi peserta didik dalam pembelajaran akan mampu meningkatkan hasil belajarnya. Peserta didik yang banyak terlibat dalam pembelajaran dengan model Dick \& Carey memiliki rata-rata skor hasil belajar kognitif lebih tinggi dibandingkan dengan peserta didik yang mengikuti pembelajaran konvensional. Proses pembelajaran dengan model Dick \& Carey ini juga sesuai dengan paradigma pembelajaran konstruktivistik yang menekankan pengembangan kemampuan peserta didik dalam menemukan jawaban atas permasalahan yang berhubungan dengan masalah yang sedang dikaji (Nur, 2000).

Menurut Sardiman (2007), menjelaskan bahwa belajar akan lebih optimal dan efektif bila didorong dengan adanya motivasi, terutama motivasi dari dalam (instrinsic motivation). Motivasi akan senantiasa menentukan intensitas usaha belajar bagi para siswa, sehingga motivasi dapat berfungsi sebagai pendorong usaha dan pencapaian prestasi. Selain itu, menurut pendapat Mulyasa (2004), bahwa pengalaman belajar dalam modul membantu siswa mencapai tujuan belajar secara efektif dan efisien serta memungkinkan siswa belajar aktif tidaksekadar membaca mendengar tapi modul memberikan kesempatan pada siswa untuk bermain peran, simulasi dan 
berdiskusi. Dengan demikian pengalaman belajar siswa akan lebih bermakna.

\section{Pengaruh Bahan Ajar Teori Evolusi dengan Model Dick \& Carey terhadap Hasil Belajar Sikap}

Hasil penelitian ini menunjukkan bahwa dengan Bahan Ajar Teori Evolusi dengan Model Dick \& Carey berpengaruh nyata terhadap hasil belajar Sikap peserta didik. Berdasarkan hasil pengujian statistik pada pengaruh Bahan Ajar Teori Evolusi dengan Model Dick \& Carey terhadap Hasil sikap menunjukkan nilai $\mathrm{F}$ hitung sebesar 40.873 dengan nilai $p=0.000$ lebih kecil dari nilai alpha 0.05 yang berarti hipotesis nol ditolak dan hipotesis penelitian diterima yang menyatakan ada pengaruh perbedaan perangkat Bahan Ajar Teori Evolusi dengan Model Dick \& Carey terhadap hasil belajar Sikap. Pada uji lanjut diketahui bahwa perbedaan mean yang terkoreksi dari Bahan Ajar Teori Evolusi dengan Model Dick \& Carey memiliki nilai 74.5221 lebih tinggi dibandingkan dengan strategi pembelajaran konvensional yaitu sekitar 69.3543 atau dengan kata lain Bahan Ajar Teori Evolusi dengan Model Dick \& Carey lebih baik dari konvensional terhadap hasil belajar sikap.

Bahan Ajar Teori Evolusi dengan Model Dick \& Carey berpengaruh terhadap motivasi mahasiswa. Penggunakan modul berpengaruh terhadap kemandirian siswa dalam mengkonstruk pengetahuannya sendiri sangat berpengaruhi hasil belajar siswa itu sendiri. Oleh karena itu setiap siswa selalu berusaha mendapatkan hasil yang terbaik baik dalam kerja kelompok maupun dalam kerja individu.Hal ini sesuai dengah hasil penelitian Nuning Merduwati (2008) mengemukakan dengan pembelajan modul kecepatan belajar siswa juga menigkat. Hal ini dapat dilihat dari kecepatan siswa untuk mengerjakan dan memahami materi dalam modul.

\section{Kesimpulan}

Hasil uji Anakova menunjukkan bahwa Bahan Ajar Teori Evolusi dengan Model Dick \&Carey berpengaruh nyata terhadap hasil belajar kognitif dengan nilai $\mathrm{F}$ hitung sebesar 32.014 dengan nilai $\mathrm{p}=$ 0.000 lebih kecil dari nilai alpha 0.05 yang berarti hipotesis nol ditolak dan hipotesis penelitian diterima yang menyatakan ada pengaruh Bahan Ajar Teori Evolusi dengan Model Dick \& Carey terhadap hasil belajar kognitif peserta didik dan hasil uji Anakova pada pengaruh Bahan Ajar Teori Evolusi dengan Model Dick \& Carey terhadap hasil sikap menunjukkan nilai $\mathrm{F}$ hitung sebesar 40.873dengan nilai $\mathrm{p}=$ 0.000 lebih kecil dari nilai alpha 0.05 yang berarti hipotesis nol ditolak dan hipotesis penelitian diterima yang menyatakan ada pengaruh perbedaan perangkat Bahan Ajar Teori Evolusi dengan Model Dick \& Carey terhadap hasil belajar Sikap.

\section{Saran}

Berdasarkan kesimpulan yang diperoleh dalam penelitian ini, maka dapat diajukan saran yang perlu menjadi pertimbangan bagi semua pihak yang berkepentingan adalah sebagai berikut.

1. Bagi perguruan tinggi, hendaknya perlu merancang perangkat pembelajaran yang sesuai dengan tingkat pendidikan sebagai suatu bentuk pelayanan kepada mahasiswa dan hasil penelitian dapat digunakan sebagai acuan.

2. Bagi dosen, khususnya dosen mata kuliah biologi dapat menggunakan hasil penelitian ini berupa perangkat pembelajaran sebagai suplemen karena pengembangan perangkat pembelajaran dan strategi ini mampu memberdayakan kemampuan berpikir kritis dan juga mampu meningkatkan hasil belajar kognitif dan SikapMahasiswa.

3. Bagi peneliti lain yang berminat menggunakan bahan ajar teori evolusi dengan model dick \& carey yang juga merupakan pengembangkan perangkat 
pembelajaran melalui strategi pembelajaran konstruktivistik belum banyak diteliti dan diimplementasikan dalam pembelajaran di kelas.

\section{DAFTAR PUSTAKA}

Ariyanto. 2006. Pengolahan Data Statistik dengan SPSS 14. Jakarta: Salemba Infotek.

Arikunto, S. 2001. Dasar-dasar Evaluasi Pendidikan. Jakarta: Bumi Aksara.

BSNP, 2006.Badan standarisasi Nasional Pendidikan.Dekdikbud. Jakarta

Campbell, Reece, Mitchell. 2003. Biologi jilid 2. Jakarta: Erlangga

Depdiknas.2002. Pendidikan Berorientasi Kecakapan Hidup (Life Skill) melalui Pendekatan Broad-Based Education $(B B E)$. Jakarta: Tim Broad-Based Education Depdiknas.

Dick, W. and Carey, L. 1990.The Systematic Design of Intruction. New York : Harper Colling Publisher.

Hart, D. 1994. Authentic Assesment A Hand Book for Educators. New York: Addison-Wesley Publishing Company.

Hanggono. 2010. Perkembangan Biologi Molekuler Tuntut Transformasi Kurikulum, (Online) (Universitas Padjadjaran » Blog Archive » Perkembangan Biologi Molekuler Tuntut Transformasi Kurikulum.htm, diakses tanggal 9 Maret 2010)

Liliasari. 2000. Model Pembelajaran untuk Meningkatkan Keterampilan Berpikir Konseptual Tingkat Tinggi Calon Dosen IPA. Prosiding Seminar Nasional, Malang,23 Pebruari 2000. Malang: Ditjen Dikti Depdiknas-JICA-IMSTEP. Hlm 135-140.

Merduwati, Nuning.2008.Penerapan Pembelajaran Modul Pencemaran lingkungan dengan Model Siklus Belajar $4 e$ (the 4e learning cycle) Untuk Meningkatkan Motivasi dan Hasil Belajar
Siswa Kelas X Man Malang I Skripsi tidak dipublikasikan UM Malang.

Muchtarijah, Husnul, 2009, Bila Siswa Tanya Teori Harun Yahya(Artikel), Surabaya, Jawa Pos. Diakses tanggal 11 Februari 2009.

Mulyasa, E. 2004. Kurikulum Berbasis Kompetensi. Bandung: PT Remaja Rosda Karya

Nasution, S. 1988. Berbagai Pendekatan dalam Proses Belajar Mengajar. Jakarta: Bina Aksara.

Nur, M. 2000. Pengajaran Berpusat kepada Siswa dan Pendekatan Konstruktivis dalam Pengajaran. Surabaya: UNESAUniversity Press.

Nurhadi, Y.B. dan Senduk, A.G. 2004.Pembelajaran Kontekstual dan Penerapannya dalam KBK. Malang: Universitas Negeri Malang Press.

Sardiman. 2007. Interaksi dan Motivasi Belajar Mengajar. Jakarta: Rajawali Press Sudijono, A. 2006. Pengantar Evaluasi Pendidikan. Jakarta: Raja Grafindo Persada.

Sudrajat Akhmad. 2010. Tentang

Pendidikan (online

http://akhmadsudrajat.wordpress.com/20 10/08/20/pendidikan-karakter-di-smp/ di akses tanggal 23 februari 2012)

Sugiyono. 2003. Statistik untuk Penelitian. Bandung: Alfabeta.

Sujana, N. 1994. Desain dan Analisis Eksperimen. Bandung: Tarsito.

Suparno, P. 2001. Filsafat Konstruktivisme dalam Pendidikan. Yogyakarta: Kanisius.

Surapranata, S. 2004. Analwaswas Validitas, Reliabilitas, dan Interpretasi Hasil Tes Implementasi Kurikulum 2004. Bandung: Remaja Rosda Karya. 